\title{
THE EFFECT OF EMPOWERMENT TOWARDS WORK ETHOS AND THE QUALITY OF POOR FAMILY LIVING
}

\author{
Permadhi Ade Krisna*, Setiawina Nyoman Djinar \\ Faculty of Economics and Business, University of Udayana, Bali, Indonesia \\ *E-mail: krisnapermadhi11@gmail.com
}

\begin{abstract}
The inherent values, attitudes, and apathetic behavior in the lives of poor families, refusing to work hard will have implications for imbalances in family life especially in the majority of Hindu poor families. A constructive efforts is needed to overcome mental degradation, moral and cultural values, attitudes and behavior. A change in mindset of poor families that poverty can be changed with hard work is very necessary. Empowerment is an effort to increase the capacity of the community to accelerate moving out of poverty by growing awareness, confidence, and a strong desire that poverty can be changed by working hard and not solely caused by destiny. Therefore work ethic is a behavioral aspect that is to be realized in empowerment. In the holy book of the Vedas it was found that the values of the work ethic of Hindus include: creativity, hard work without knowing despair, respect for time, harmonious cooperation, satya discourse, ethical (efficient) efficiency and full of initiative. Work ethic in a person will create enthusiasm and confidence to run a business seriously to get out. In other words, among poor families there will be shame if they are always pitied and driven to live independently and are always oriented towards improving the quality of life. The higher the work ethic of a person will undoubtedly increase the quality of life, and vice versa.
\end{abstract}

\section{KEY WORDS}

Empowerment, work ethic, quality of life, poor families.

People have a very close relationship with the intensity of development that occurs. As the main actor in development, placing residents as an integral part of the overall development process is believed to accelerate development goals. The rapid increase in population will have implications for meeting their basic needs. Given the differences in education levels and skill levels and limited ability to access employment opportunities, limitations in fulfilling them will create problems of poverty and powerlessness, and have a broad impact on other aspects of life in society.

Bali as part of the Indonesian state also faces the problem of poverty (Sri Budhi, 2013). When viewed in the period of 2012 to 2017, poverty rates tend to fluctuate. In 2012 the percentage of poor people in the province of Bali was 3.95 percent, and moved up to touch the percentage of 4.49 percent in 2013. In the next period, poverty tended to increase where in 2015 it reached 4.76 percent and moved again decreased to 4.25 percent in 2016 and 2017. The districts of Karangasem, Klungkung and Buleleng in the 2013 to 2017 period were the three districts with the highest percentage of poverty in the Province of Bali.

Table 1 - Percentage of Poor Population in Bali Province in 2012-2017

\begin{tabular}{|c|c|c|c|c|c|c|}
\hline \multirow{2}{*}{ Regency / City } & \multicolumn{6}{|c|}{ Percentage of Poor Population (percent) } \\
\hline & 2012 & 2013 & 2014 & 2015 & 2016 & 2017 \\
\hline Jembrana & 5.74 & 5.56 & 5.83 & 5.84 & 5.33 & 5.38 \\
\hline Tabanan & 4.90 & 5.21 & 5.61 & 5.52 & 5.00 & 4.92 \\
\hline Badung & 2.16 & 2.46 & 2.54 & 2.33 & 2.06 & 2.06 \\
\hline Gianyar & 4.69 & 4.27 & 4.57 & 4.61 & 4.44 & 4.46 \\
\hline Klungkung & 5.37 & 7.01 & 7.01 & 6.91 & 6.35 & 6.29 \\
\hline Bangli & 4.52 & 5.45 & 5.86 & 5.73 & 5.22 & 5.23 \\
\hline Karangasem & 5.63 & 6.88 & 7.30 & 7.44 & 6.61 & 6.55 \\
\hline Buleleng & 5.19 & 6.31 & 6.79 & 6.74 & 5.79 & 5.74 \\
\hline Denpasar & 1.52 & 2.07 & 2.21 & 2.39 & 2.15 & 2.27 \\
\hline Bali Province & 3.95 & 4.49 & 4.76 & 4.74 & 4.25 & 4.25 \\
\hline
\end{tabular}

Source: Bali Province Central Statistics Agency (2018). 
Various poverty reduction programs carried out so far have shown seriousness in poverty reduction, but the various policies cannot significantly reduce the number of poor people. The poverty rate that is still experiencing fluctuations from year to year in the Province of Bali indicates that poverty reduction has not been fully implemented (Mega Putri and Yuliarmi, 2013; Margareni et al., 2016). This also indicates that poverty alleviation programs have not been running effectively as expected (Murjana Yasa, 2008; Marhaeni et al., 2014). On the other hand, although the province of Bali has been supported by a number of districts with various potentials, the classic problem of poverty still leaves poor households in the area (Margareni et al., 2016).

Poverty occurs when a household fails to reach a certain level of welfare and is measured using the Poverty Line (GK). The poverty line is measured based on household per capita expenditure to meet basic food and non-food needs, and a household is said to be a poor household if its income falls below the poverty line. In this regard, in addition to being able to reduce the number of poor people, policies related to poverty must also be able to reduce the depth and severity of poverty (BPS, 2014; Wahyuningsih, 2014; Zebua et al., 2015; Purwantini and Rusastra, 2015; Nasution et al. 2018). But in reality, although the number of poor people is relatively declining, the poverty depth and severity index tends to fluctuate and relatively increase in 2017.

According to Diana Dewi et al. (2019) it is necessary to continue efforts to be able to reduce the percentage of poor people in the Province of Bali, especially for Karangasem, Klungkung, and Buleleng Regencies even though poverty has decreased. Karangasem Regency shows the highest percentage of poor population in Bali Province, then the second is Klungkung Regency, and the third is Buleleng Regency, the three districts as the three districts with the highest percentage of poor population influenced by several factors, including: geographical conditions, infrastructure tends to be inadequate compared to other districts, economic access, education and health are still limited and inadequate, and empowerment of human resources are still underdeveloped.

It is interesting to note, among the three regencies / cities with the highest percentage of poverty in Bali, the depth and severity index of poverty in Klungkung Regency is the best quality of the decline. The poverty depth index decreases, illustrating the decreasing poverty rate, where the distance between the expenditure of the poor population and the poverty line will get closer so that the quality of life is increasing. Whereas the decrease in poverty severity index illustrates that the even distribution of expenditure among the poor population in Klungkung Regency. This shows that poor individuals or families in Klungkung Regency have gradually reached the level of minimum welfare and are able to overcome the deterioration experienced, so that it will accelerate them out of poverty and poverty more easily to be alleviated.

Table 2 - Poverty Depth Index and Poverty Severity Index In Regencies / Cities in Bali Province in 2015-2017

\begin{tabular}{ccccccc}
\hline \multirow{2}{*}{ Regency / City } & \multicolumn{3}{c}{$\begin{array}{c}\text { Poverty Depth Index (P1) } \\
\text { by Regency / City }\end{array}$} & \multicolumn{3}{c}{$\begin{array}{c}\text { Poverty Severity Index (P2) } \\
\text { by Regency / City }\end{array}$} \\
\cline { 2 - 7 } & 2015 & 2016 & 2017 & 2015 & 2016 & 2017 \\
\hline Jembrana & 0.83 & 0.53 & 0.86 & 0.19 & 0.08 & 0.19 \\
Tabanan & 0.50 & 0.57 & 0.69 & 0.09 & 0.12 & 0.13 \\
Badung & 0.17 & 0.19 & 0.21 & 0.02 & 0.05 & 0.05 \\
Gianyar & 0.56 & 0.43 & 0.57 & 0.1 & 0.07 & 0.11 \\
Klungkung & 1.00 & 0.78 & 0.33 & 0.22 & 0.13 & 0.04 \\
Bangli & 0.77 & 0.63 & 0.52 & 0.17 & 0.12 & 0.10 \\
Karangasem & 1.01 & 0.58 & 0.87 & 0.2 & 0.09 & 0.18 \\
Buleleng & 0.73 & 0.75 & 0.72 & 0.14 & 0.15 & 0.14 \\
Denpasar City & 0.24 & 0.20 & 0.40 & 0.04 & 0.03 & 0.12 \\
\hline Bali & 0.66 & 0.51 & 0.68 & 0.14 & 0.09 & 0.16 \\
\hline
\end{tabular}

Source: Bali Province Central Statistics Agency (2018). 
Culture of poverty seems to be one aspect of why most Indonesian people are still below the poverty line (Suartha, 2013). Poverty is related to the attitude (mentality) of the poor themselves to get out of the cycle of poverty (Nurkse, 1953; Oscar Lewis, 1988; Sen, 1998; Ortigas, 2000; Blomquistt, 2002; Markum, 2009; Murjana Yasa, 2008; Amidi in Mustika, 2013; Suartha, 2013 and Marhaeni et al., 2014). The attitudes that will be taken by a poor household will influence their empowerment (Oscar Lewis, 1988).

It is worth observing, the Regent of Klungkung, Nyoman Suwirta (Tribunnews.com dated July 26, 2017) stated that one of the causes of poverty is still high in his area is the mentality of people who are accustomed to receiving aid, so that a program to change the "mindset" of the poor is needed. If related to the success in reducing poverty in Klungkung Regency quality, it can be realized because productive population in Klungkung who works more than 35 hours per week is increasing, meaning that the percentage of productive population who work under 35 hours per week is relatively decreasing (below 29 percent) (Nyoman Suwitra-Gema Santi). The description indicates that the phenomenon of poverty reduction in quality in Klungkung Regency as the District with the second highest percentage of poverty in the Province of Bali is driven by an increase in morale supported by a poverty program to change the mindset of the poor.

According to Narayan, Prichett, and Kapoor (2009), the situation of poor people who are isolated, passive, lazy, helpless, worthless, have low aspirations, and alcoholics and criminal offenders are not entirely true because the poor are reliable and various fighters the way they do it to get out of poverty. Akhmadi (2006) states that individual or community motivation reflected by a strong willingness to work hard supported by community education and skills, and supported by various government programs and non-governmental organizations is an invaluable asset for local communities to accelerate moving out of poverty (moving out of poverty). As for Marhaeni et al. (2014) states that internal factors from non-physical resources such as motivation, determination, willingness, effort and hard work to get out of the shackles of poverty, are very important, and perhaps determination, willingness, hard work or motivation which would be more factors important than physical resources to get out of the cycle of poverty.

Freire (1992) explains that the process of empowerment is a method that seeks to change perceptions including changing one's motivation or encouragement in the community environment, thus enabling individuals to adapt to their environment, fostering awareness and motivation or encouragement within a person, actually requiring intervention or stimulation from outside, such as stimulation or stimulation of grants from the government, the environment associated with it and others. Empowerment is essentially a social change in society, people's attitudes and behaviors need to be changed towards positive and creative attitudes and encourage people to be more empowered. It is hoped that mental poverty which is also a cause of poverty can be eroded, so that when aid comes, they will accept it as an empowerment effort that must be developed, not as a gift that can worsen their mentality, where shame will arise if they are always pitied so that they are encouraged to live independently, full of creativity, and always oriented towards improving the quality of self.

Empowerment, is an effort to increase the capacity of the community, both individually and in groups, in solving various problems related to efforts to improve the quality of life, independence and welfare to get out of the circle of poverty (Suartha, 2013). Empowerment is a tool to help individuals, groups and communities so that they are able to manage the environment and achieve their goals, so that they are able to work and help themselves and others to maximize quality of life (Adams, 2003). In order to change the mental attitude of dependency and develop a work ethic, foster independence, raise awareness of the poor to carry out productive activities so that there is an increase in income and can reduce poverty, aspects of empowerment need to be emphasized more in poverty alleviation programs undertaken (Sukidjo, 2009). A powerless society is a society that has knowledge, skills and actions towards one's potential, and has a high work ethic which is an aspect of empowerment behavior that is to be realized (Utami, 2006). In this regard, in order to achieve the goal of community empowerment activities, it is necessary to develop a strong work ethic 
that must be carried out by instilling the values of hard work, economical, confident openness, responsibility, touted as part of the empowerment effort (Bagong Suyanto, 2001).

The belief or understanding in the family that poverty is a 'destiny' or a letter of fate that must be accepted, will relax their efforts to get out of poverty and have implications for the low efforts made to get out of poverty, so it becomes very important to grow awareness of the power that is in yourself to get out of poverty. According to Suartha (2013) a change in the perception of the poor that "poverty can be changed by working hard" shows a sense of confidence that they can get out of poverty, and does not quite believe that poverty is caused by destiny, and shows a strong enough desire to get out from poverty. Every human being in this case the poor family has the potential that can be developed, therefore, to be able to get out of poverty, it needs a change in attitude and behavior change, because the attitude of accepting the situation (resignation) is a reflection of the poor family.

The inherent values, attitudes, and apathy in the life of the poor, so lazy to work hard will have implications for imbalances in family life which are predominantly Hindu. Hinduism believes that belief (sraddha) will be felt in life if it is actually manifested in the form of work (karma) that is beneficial to life in the world. In the Hindu view work is something that is essential for human life and is an obligation for all people. One will not achieve happiness silently without work and will not achieve perfection and freedom by avoiding work (Gorda, 1996). In the holy book of the Vedas also found that the values of the work ethic of Hindus include: creativity, hard work without knowing despair, respect for time, harmonious cooperation, satya discourse, ethical efficiency and full of initiative (Gorda, 1966; Gunawan, 2011)

The process of community empowerment is rooted strongly in the process of independence of each individual which then extends to the family, as well as community groups. The family is an important target in the actual empowerment program in an effort to improve dignity and status while in poverty. Empowerment will be able to independent and empower poor families to be empowered. Therefore, through empowerment, poor families will have greater confidence in their abilities, no longer have to surrender to fate, and see poverty not as fate, which is followed by the emergence of a work ethic for the sake of improving the quality of life.

\section{DISCUSSION OF RESULTS}

In general poverty is defined as a condition of income inability to meet basic needs and other needs that can guarantee the fulfillment of quality of life standards (Jacobus et al, 2018). The concept of welfare is inseparable from the quality of life of the people (Widyastuti, 2012). Quality of life is a variety of human experiences, one of which is related to overall well-being. Welfare according to Behnke and Macdermid (2004) is defined as the quality of life which consists of various aspects, both economic, social, and psychological. According to the World Health Organization (1996), quality of life is an individual's perception of an individual's position in life according to the cultural context and value system adopted, where the individual lives and his relationship with expectations, goals, standards set and attention from individuals. Problems that cover the quality of life are very broad and complex, including problems of physical conditions, psychological conditions, social relationships, relationships with the environment.

Felce and Perry (1995) group the aspects of quality of life that most often appear into five major groups of aspects of quality of life namely physical wellbeing aspects (consisting of aspects of health, fitness, physical security, and mobility), material wellbeing, (consisting from aspects of income, environmental quality, privacy, ownership, food, transportation, living environment, security and stability), social wellbeing (consisting of interpersonal relationships and community involvement), development and activity, emotional wellbeing (consisting from affect or mood, satisfaction or fulfillment of needs, self-confidence, religion, and status / honor). Whereas BPS (2017) to facilitate the interpretation of changes in the level of welfare as a reference in efforts to improve the quality of life, assesses according to eight areas, including: (a) population, (b) health and nutrition, (c) education, (d) employment, (e) levels 
and patterns of consumption, (f) housing and the environment, (g) poverty, and (h) other social conditions.

Understanding in Hinduism believes that it will be felt in life if it is actually manifested in the form of work (karma) that is beneficial to life in the world (Anggraeni, 2018). Work is an obligation for everyone. One will not achieve happiness silently without work and will not achieve perfection and freedom by avoiding work (Gorda, 1996). Humans who have and live a work ethic based on the spirit of sacrifice (yadnya) and view work as God's commandment (titah Ida Sang Hyang Widhi Waça) which will be able to overcome the various problems and challenges of life in the world, especially in life that is surrounded by an atmosphere of globalization and liberalization. In the holy book of the Vedas also found that the values of the work ethic of Hindus include: creativity, hard work without knowing despair, respect for time, harmonious cooperation, satya discourse, ethical efficiency and full of initiative (Gorda, 1966; Gunawan, 2011), described as follows: (a) Creativity is a way of maintaining survival in an atmosphere of competition and full of change through continuous innovation; (b) Hard work is a human effort to improve the quality of humanity and shape human identity without tireless and hopeless; (c) Appreciate time means to use the time as well as possible in order to really bring benefits to human life and do not delay work based on dharma; (d) Harmonious cooperation is to help others who face difficulties or be overtaken by misfortune in achieving their intended goals; (e) satya wacana constitutes a promise whose law must be obeyed to the decisions that have been taken in his life based on honesty; (f) an ethical frugal life is a view of patterns of income use (artha) not solely for the sake of satisfying daily needs, but also used for religious purposes and funds punya; (g) full of initiative is a person who prioritizes proactive rather than reactive in facing challenges and problems of his life.

Deepa Narayan (2002) provides an understanding that "Empowerment is the expansion of assets and capabilities of poor people to participate in, negotiate with, influence, control, and hold accountable institutions that affect their lives". From this understanding, it can be concluded that community empowerment is an effort to prepare and strengthen assets and potentials of poor communities to be able to participate in controlling and strengthening community institutions, so as to realize progress and independence. Thus, community empowerment is an effort to increase the dignity of the layers of society who are unable to escape the pitfalls of poverty and underdevelopment. Ife (1995) states that increasing the power of the disadvantaged, it is necessary to look not only at what constitute power, but also at the nature of disadvantage. Empowerment is done to give power to the disadvantaged so that they become empowered. Community Empowerment is aimed at increasing the empowerment of the poor so that they are able to actively participate in the development process. With greater community participation, poverty alleviation efforts are expected to be more sustainable. Payne (1997) argues that an empowerment process is essentially aimed at: "To help clients gain power of decisions and actions over their own lives by reducing the effect of social or personal blocks to exercising existing power, by increasing capacity and self confidence to use power and by transferring power from the environment to clients". Wrihatnolo and Nugroho (2007) stated that empowerment is basically a process that is carried out with full awareness and participation of the parties to increase the capacity and capability of the community as a development resource in order to be able to recognize the problems faced in developing and helping themselves towards better conditions, able explore and make use of available resources for the benefit of themselves and their groups, and be able to express themselves clearly by benefiting from it.

As a process, empowerment has three stages, namely awareness, capacity building, and empowerment. Awareness stage, where the target is the poor are given an understanding that they have the right to be, have the ability to get out of poverty and understand that the empowerment process must originate from themselves.

The capacity building phase aims to enable the poor so that they have the skills to manage the opportunities that will be provided, through trainings, workshops and similar activities aimed at improving the life skills of the poor and opening access to key resources outside their communities as a bridge to realize his hopes and existence. While at the empowerment stage, where the poor are given opportunities tailored to their abilities through 
active and sustainable participation that is taken by giving a greater role in stages according to their capacity and capabilities, their aspirations are accommodated and guided to conduct self-evaluations of the choices and results of implementation top choice.

The next stage of empowerment is to create an independent community that is sustainable, as a manifestation of a prosperous society, where there have been efforts to meet their own needs with their own efforts without depending on others, in accordance with their potential and capacity and avoiding a culture of rapid complacency. and feel enough.

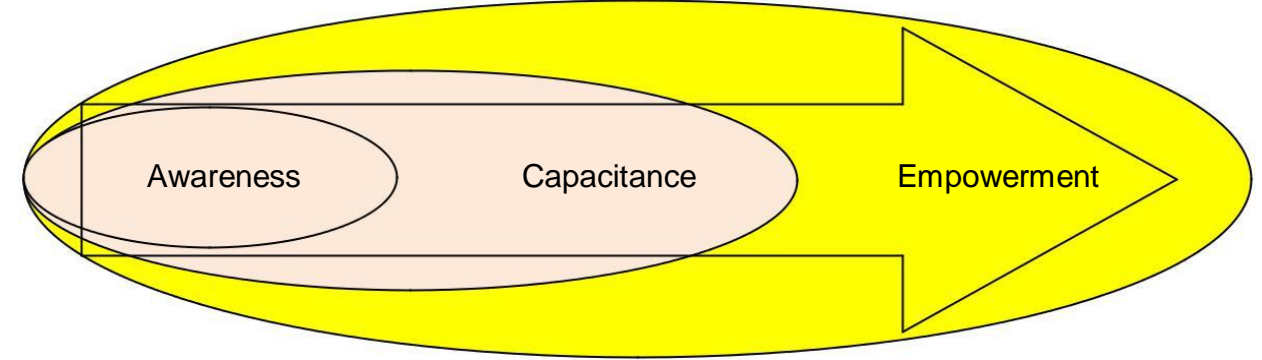

Figure 1 - Empowerment Stages (Source: Wrihatnolo and Nugroho, 2007)

Freire (1992) explains that the process of empowerment is a method that seeks to change perceptions including changing one's motivation or encouragement in the community environment, thus enabling individuals to adapt to their environment, fostering awareness and motivation or encouragement within a person, actually requiring intervention or stimulation from outside, such as stimulation or stimulation of grants from the government, the environment associated with it and others. Andreas and Savitri (2016) found that the presence of the four businesses of the Coastal Community Economic Program (PEMP) in the midst of coastal communities (fishermen), namely the ease of access to fuel needs, business capital, institutional improvement of fishermen's economy and coastal shops has provided motivation work for their business, which is to increase their enthusiasm in working as a result of the implementation of the PEMP program in the coastal areas of Meranti Regency and Rokan Hilir Regency. The work spirit can implicitly develop with the presence of community empowerment, where the potential for productive work that has long been stored, revived by the stimuli (motivation) by the presence of EMP empowerment poured out by the government as a stimulant or motivation that is strong enough in reviving the morale productive of the fishermen for the better.

\section{CONCLUSION}

Poverty will continue to be a major obstacle to development success. Various poverty reduction programs carried out so far have shown seriousness in poverty reduction, but these various programs have not been able to significantly reduce the number of poor people. These poverty programs have not been able to shift the behavior of poor families to get out of poverty, so that the mental attitude of poor people who tend to surrender, accept what they are, feel poor is fate / destiny is still embedded in the mental structure of poor families. To be able to get out of poverty requires changing attitudes and changing behavior, because the attitude of accepting the situation (resignation) is a mirror of poor families, so it needs constructive efforts to overcome mental degradation, moral and cultural values, attitudes and behavior. In order to change the mental attitude of dependency and develop a work ethic, foster independence, raise awareness among the poor to carry out more productive activities so as to reduce poverty, it is necessary to emphasize more on the empowerment aspects of each poverty alleviation program undertaken. Empowerment of poor families is believed to be able to eliminate mental poverty so that when assistance is given they will accept it as an effort that must be developed, so that shame will arise if it fails, driven to live independently, full of creativity, and oriented to improving the quality of life. 
Individual or community motivation reflected by a strong willingness to work hard which is supported by community empowerment is an invaluable asset for local communities to accelerate moving out of poverty. A change in mind set or mindset is a basic thing that wants to be improved in an empowerment process for poor families, and sees that poverty can be changed by working hard and not destiny. From these changes will bring initiatives from the community to not be trapped in poverty and can rise from all forms of poverty, improve their work ethic for the sake of improving the quality of life.

\section{REFERENCES}

1. Andreas and Eni Savitri. 2016. Peran Pemberdayaan Ekonomi Masyarakat Pesisir (Dalam Meningkatkan Kesejahteraan Di Kabupaten Meranti and Rokan Hilir). Cetakan 1.

2. Badan Pusat Statistik. 2017. Indikator Kesejahteraan Rakyat. Katalog BPS: 4102004

3. Chambers, R. 1987. Pembangunan Desa Mulai Dari Belakang. Jakarta: LP3ES.

4. Deepa Narayan. 2002. Empowerment and Poverty Reduction: A Source book. Washington DC: The World Bank.

5. Freire, Paulo. 1992. Pedagogy of The Oppressed. Harmondsworth: Penguin Books, Inc.

6. Gorda, I Gusti Ngurah. 1996. Etika Hindu and Perilaku Organisasi. Sekolah Tinggi IImu Ekonomi Satya Dharma Singaraja. ISBN: 979-8620-3-8.

7. Gunawan, Ketut. 2011. Peran Falsafah Tri Hita Karana Bagi Pertumbuhan and Kinerja Lembaga Perkreditan Desa (Lpd) Di Bali . Analisis Manajemen. Vol. 2 No. 5. Fakultas Ekonomi Universitas Panji Sakti Singaraja-Bali.

8. Ife, Jim. 1995. Community Develompment Creating Community Alternatives Vision Analysis and Practise. Australian: Longman.

9. Manuaba, I. M., Triguna, I. B. G., \& Wirawan, I. G. B. 2019. Cultural Poverty Within the Life of Hindu Poor People in Karangasem Regency. International Journal of Interreligious and Intercultural Studies, Vol 2, No. 1, pp 92-102.

10. Marhaeni, A.A.I.N., I Ketut Sudibia., I GAP Wirathi., Ni Nyoman Yuliarmi., Ni Putu Martina Dewi. 2014. Evaluasi Program-Program Pengentasan Kemiskinan Pada Kluster 2 Di Provinsi Bali. Laporan Penelitian. FEB Universitas Udayana.

11. Nadjib. 2013. Agama, Etika and Etos Kerja Dalam Aktivitas Ekonomi Masyarakat Nelayan Jawa. Jurnal Ekonomi and Pembangunan Vol 21, No. 2, Hal. 138-150.

12. Nurkse, R. 1953. Problems of Capital Formation in Underdeveloped Countries. Oxford.

13. Lewis, Oscar. 1988. Kisah Lima Keluarga. Telaah-telaah Kasus Orang Meksiko dalam Kebudayaan Kemiskinan: Yayasan Obor Indonesia, Jakarta.

14. Ortigas, C. D. (2000). Poverty revisited. A social psychological approach to community empowerment. Manila: Ateneo de Manila University Press.

15. Sen, Amartya. 2000. Development As Freedom. NY: A Division of random house, Inc.

16. Suartha, Nyoman. 2013. Pengaruh Kapasitas Rumah Tangga, Budaya and Pemberdayaan Terhadap Sikap Serta Keberdayaan Rumah Tangga Miskin di Kabupaten Karangasem. Disertasi. Universitas Udayana.

17. Suharto E. 2005. Membangun Masyarakat Memberdayakan Rakyat: Kajian strategis Pembangunan Kesejahteraan Sosial \& Pekerjaan Sosial. Bandung: Refika Aditama.

18. Payne, M. 1997. Social Work and Community Care. London: McMillan.

19. Puspa, DM., I M Suyana Utama., I M Kembar Sri Budhi., M Henny Urmila Dewi. 2017. Effect Of Social Economic Factors On Quality Of Life: A Structural Model In Schizophrenia People In Bali Province-Indonesia. International Journal Of Economics, Commerce and Management. Vol. 9, Issue 9. ISSN: 2348 0346. United Kingdom.

20. Putra, Made Gunarsa., Nyoman Djinar Setiawina., I. Gst Wayan Murjana Yasa. 2017. Analisis Pegaruh Faktor Produksi, Sosial Demografi, and Modal Sosial terhadap Produktivitas and Kesejahteraan Rumah Tangga Nelayan di Kabupaten Tabanan. E-Jurnal Ekonomi and Bisnis Universitas Udayana. ISSN: 2337-3067.

21. Todaro, 2003. Pembangunan Ekonomi di Dunia Ketiga. Jilid, Edisi Kedelapan. Erlangga.

22. Wrihatnolo, Nugroho D. 2007. Manajemen Pemberdayaan: Sebuah Pengantar and Panduan untuk Pemberdayaan Masyarakat. Jakarta. PT. Elex Media Komputindo. 